\title{
Micropaleontological observations on the Lower Cretaceous iron ore-related formations of the Mecsek Mts. (Upper Valanginian-Lower Hauterivian, South Hungary)
}

\author{
László Bujtor ${ }^{1 *}$, Balázs Szinger ${ }^{2}$ \\ ${ }^{1}$ Department of Geology and Meteorology, University of Pécs, Pécs, Hungary \\ ${ }^{2}$ Exploration Laboratories, MOL Hungarian Oil and Gas Company, Budapest, Hungary
}

Received: September 27, 2016; accepted: February 13, 2018

The Late Valanginian-Early Hauterivian iron ore deposit and related formations at Zengóvárkony (Mecsek Mts., South Hungary) provided a relatively rich microfauna of foraminifera, crustacean microcoprolites, and sponge spicules. Benthic foraminifera are recognized in decreasing abundance: Glomospira cf. gordialis (Jones and Parker 1860), Lenticulina sp., Spirillina sp., Nodosaria sp., Epistomina sp., and Trocholina sp. A Hedbergella sp. indicates the presence of planktonic foraminifera around the ore deposit. Besides this microfauna, sponge spicules (diactine-type criccorhabds and anactine-type rhax forms) are first recorded from this environment. Rock-forming quantities of various ichnospecies of crustacean microcoprolites are recorded. Favreina hexaochetarius, Palaxius tetraochetarius, and Palaxius decaochetarius isp. provided statistically evaluated quantities in thin sections, which point to a complete crustacean ichnofauna from juveniles to adults. Four different microfossil assemblages are recognized from the Apátvarasd Limestone Fm: (a) Glomospira-dominated foraminifer assemblage, (b) diverse crustacean microcoprolite assemblage dominated by Palaxius, (c) monotypic Favreina assemblage, and (d) diverse sponge-dominated assemblage. These assemblages are similar to that of the Recent Aegean Sea hydrothermal field communities. The remains of an undetermined crinoid from dissolved rock sample may indicate a vivid sea-bottom environment.

Keywords: iron ore deposit, Valanginian, Hauterivian, foraminifera, sponges, crustacean microcoprolites, echinoderms

*Corresponding author: László Bujtor; Department of Geology and Meteorology, University of Pécs, Ifjúság u. 6., Pécs H-7624, Hungary

E-mail: bujtor.laszlo.geology@gmail.com

This is an open-access article distributed under the terms of the Creative Commons Attribution-NonCommercial 4.0 International License, which permits unrestricted use, distribution, and reproduction in any medium for noncommercial purposes, provided the original author and source are credited, a link to the CC License is provided, and changes - if any - are indicated. 


\section{Introduction}

Microfossils from the Cretaceous of the Zengôvárkony area were first reported by Sztrókay (1952), evaluating these remnants of dasycladacean algae (Sztrókay 1952) or unidentifiable microorganisms (Pantó et al. 1955). Finally, Palik (1965) recognized their origin and reported six new crustacean microcoprolite ichnospecies: Favreina dispentochetarius, Favreina hexaochetarius, Favreina octoochetarius, Palaxius triochetarius, Palaxius tetraochetarius, and Palaxius decaochetarius. From thin sections, Palik (1965) also reported crab antennae of a possible thalassinid origin. Fülöp (in Hetényi et al. 1968) reported a macrofauna (Olcostephanus astierianus, Neolissoceras grasianum, Neocomites neocomiensis, Duvalia dilatata, Pleurotomaria sp., Rhynchonella malbosi, Cidaris sp., and Torynocrinus sp.) and some microfossils (Tintinnopsella carpathica and Globigerina sp.), to which he assigned a Late Valanginian age.

Although a rich Early Cretaceous shallow-marine foraminifer fauna from the Mecsek Mountains is already known (Vadász 1935) and is quite diverse, comprising 35 taxa (Szinger 2008), it is interpreted to be derived from an atoll environment (Császár and Turnšek 1996) around a volcanic edifice. From the iron ore deposit, the only foraminifer record (Globigerina sp.) is reported by Fülöp (in Hetényi et al. 1968). From the Kisújbánya section, Bujtor (2011) reported a $P$. decaochetarius microcoprolite isp. from thin section of a limestone olistolith of a possible Zengóvárkony origin and gave as its age as the Lower Valanginian Thurmanniceras pertransiens Zone (Bujtor 2011, 2013a). Bujtor (2012a) also reported previously unknown ichnospecies from the Bolondút Valley, in the vicinity of Zengóvárkony (Fig. 1): Palaxius darjaensis (SenowbariDaryan and Silantiev 1991) and Palaxius salataensis (Brönnimann et al. 1972). Jáger et al. (2012) also reported microcoprolite ichnospecies from the vicinity of the ore mine: Favreina belandoi (Schweigert et al. 1997), Parafavreina huaricolcanensis (SenowbariDaryan and Stanley 1986), and Helicerina siciliana (Senowbari-Daryan et al. 1969). Altogether, these species make up the most diverse crustacean microcoprolite locality of the Mesozoic (Bujtor 2012a). Recent research (Bujtor 2012a, 2012b; Bujtor et al. 2013) is focused on paleoenvironments and reported previously unknown dinoflagellates and belemnites from the iron ore body and nearby. Bujtor (2012a) reported a remarkably rich crustacean microcoprolite ichnofauna, which is of special importance to this paleoenvironment. Although foraminifera are rarely reported from the Zengóvárkony iron ore body (Fülöp in Hetényi et al. 1968), sponges have never been reported yet.

The origin of the iron ore and its environment is still ambiguous. The possible interpretation of the Zengóvárkony iron ore deposit as a candidate for a chemosynthetic vent/seep site was proposed by Bujtor (2006) based on the almost monotypic brachiopod fauna dominated by large specimens of Lacunosella (average dimensions are $70 \%$ greater than that of the mean dimensions at their type localities). These faunal characteristics (monotypic and large-sized brachiopod populations) are decisive for the recognition of fossil/recent vents/seeps, as discussed by Callender and Powell (1992). Later, Bujtor (2007) initiated a stable isotope analysis and ruled out the seep origin but proposed a genetic model and linked the iron ore deposit to the Late 


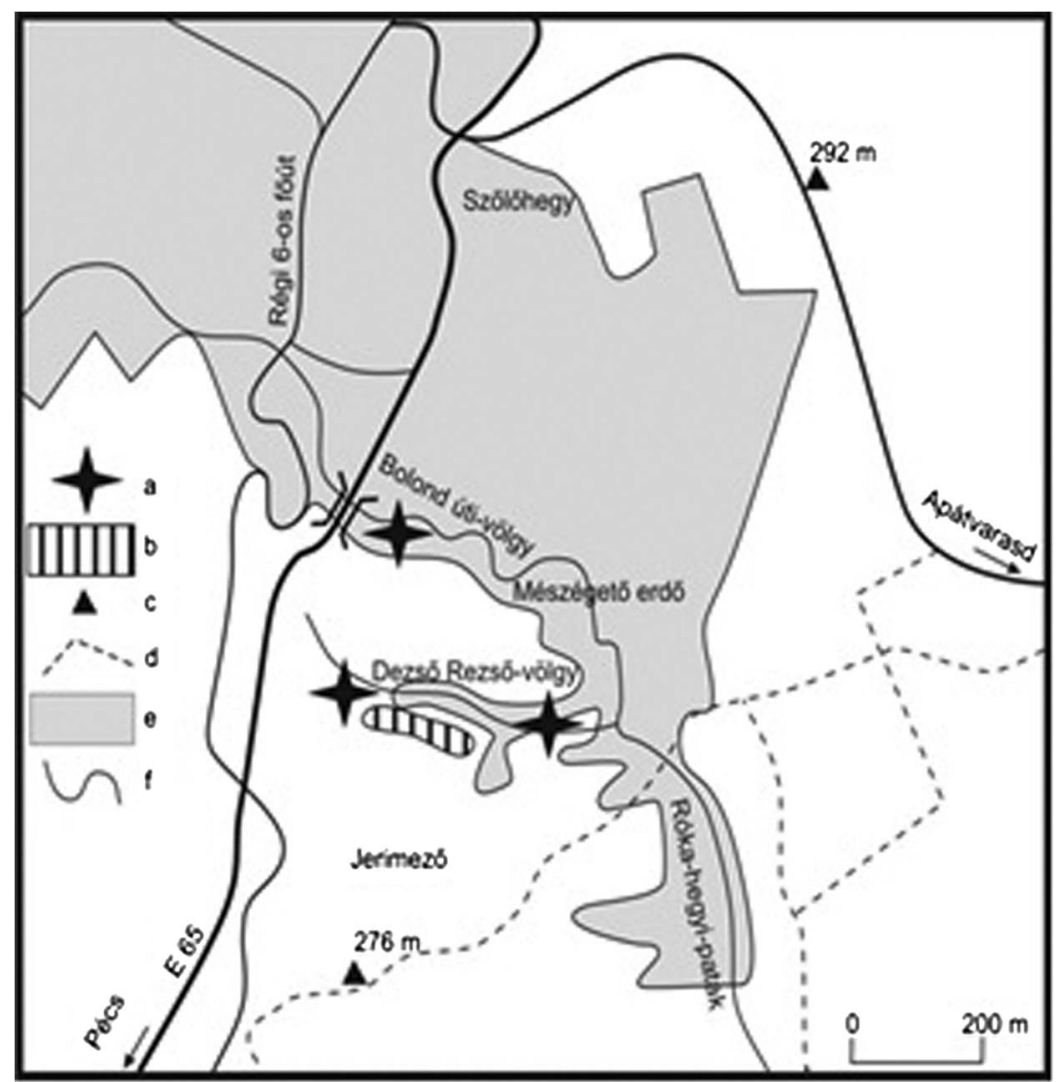

Fig. 1

Map of the vicinity of the former iron ore mine at Zengóvárkony, Mecsek Mountains, Hungary. Investigated sections are indicated by an asterisk. Map modified after Bujtor (2011, 2012a)

Jurassic-Early Cretaceous volcanism of the region. Jáger (2008) and Jáger and Molnár (2009) reported the evidence of the black smoker chimney remnants from the Dezsô Rezső Valley at Zengővárkony. However, although Jáger and Molnár (2009) reported remnants of black smoker chimneys from the Dezső Rezső Valley, later they (Jáger et al. 2012) considered these remnants hydrothermal sediments and wood-fall environments, dropping the hydrothermal vent origin. There is hardly a chance to find in situ hydrothermal vent chimneys in the area, due to the former mining activity and because of the exposure to erosion over millions of years.

The aim of this paper is to describe the results of micropaleontological observations of the iron ore-related formations and to report the rich foraminifera, sponge, and microcoprolite assemblages that are recognized in the sedimentary environment surrounding the iron ore deposit. 


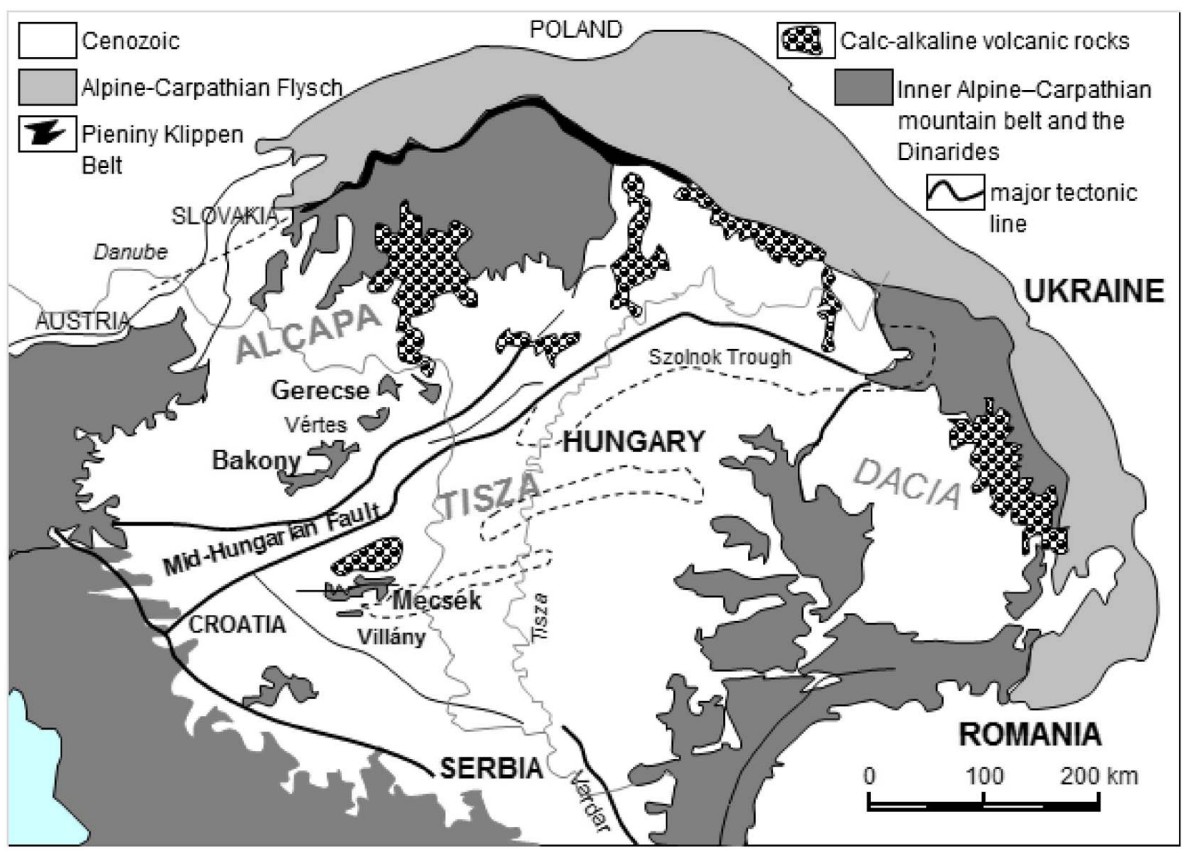

Fig. 2

Main tectonic units of the Carpathian region after Csontos and Vörös (2004); simplified and showing the position of the Tisza Unit

\section{Regional setting}

The Mecsek Mountains of South Hungary belong to the Tisza Unit (Fig. 2), which is considered a microplate (Csontos and Vörös 2004). Detachment of this microplate from the European Plate began in the Late Jurassic and was initiated by continental rifting (Harangi 1994; Huemer 1997). Intraplate alkaline basaltic volcanism terminated the continuous basinal carbonate sedimentation and produced mixed volcanosedimentary deposits (Nagy 1967; Harangi 1989, 1994). Materials of the volcanic activity are reported from distant areas $(200 \mathrm{~km}$ from the volcanic center) of the Tisza Unit (Bilik 1983). The volcanic activity resulted in an ankaramite-alkaline basaltic paleovolcano in the Mecsek Mts. (Császár and Turnšek 1996) at Magyaregregy (Fig. 3). The center of the paleovolcano was situated northwest of Magyaregregy (Wein 1961, 1965), forming a volcanic island (Császár and Turnšek 1996). Submarine volcanic bodies are reported from other places in the Eastern Mecsek Mts. and have been thoroughly investigated (Mauritz 1913, 1958; Bilik 1974, 1983). Simultaneously with the volcanism, a sedimentary iron ore body was deposited (Sztrókay 1952; Pantó et al. 1955; Molnár 1961) southeast of the volcanic center. Active mining was 


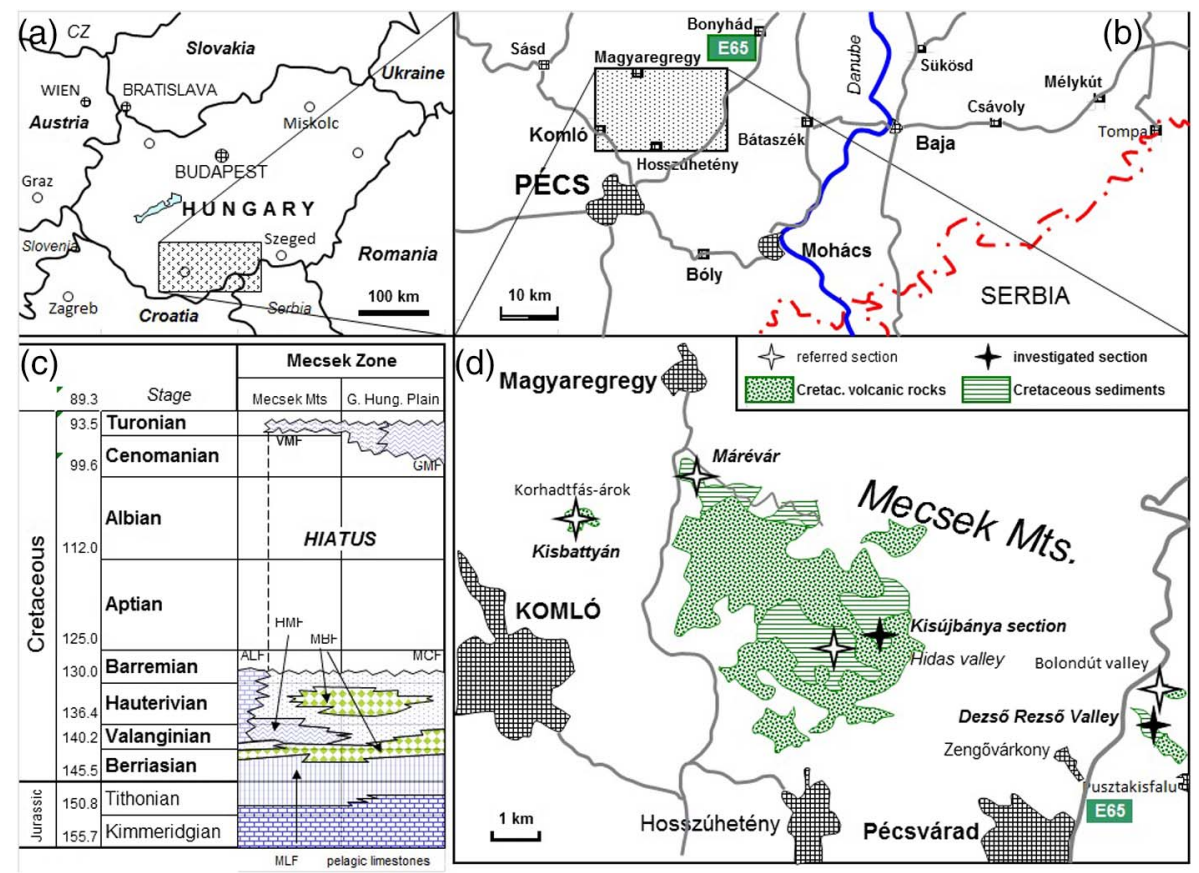

Fig. 3

(a-c) Areal distribution of the Cretaceous volcano-sedimentary formations in the Mecsek Mountains. Referred and investigated sections are indicated. Map after Vadász (1935), Fülöp (in Hetényi et al. 1968), Horváth (1968), Bujtor (1993, 2006, 2012a), Császár (2002), and Szinger (2008). (d) Lower Cretaceous formations of the Mecsek Zone after Császár (1996). ALF: Apátvarasd Limestone Fm; GMF: Gátér Marl Fm; HMF: Hidasivölgy Marl Fm; MBF: Mecsekjános Basalt Fm; MCF: Magyaregregy Conglomerate Fm; MLF: Márévár Limestone Fm; VMF: Vékény Marl Fm. Mesozoic time scale after Gradstein et al. (2004)

continuous between 1954 and 1956. The average thickness of the ore deposit was $1 \mathrm{~m}$; its dimension along strike was $600 \mathrm{~m}$. During mining some 24,850 tons of iron ore were excavated (Molnár 1961). Geologic mapping of the region provided further data by Fülöp (in Hetényi et al. 1968), assigning it a Late Valanginian age based on the macrofauna. The iron ore deposit provided an abundant and, in some places, rockforming quantity of microfossils.

The age of the ore deposit at Zengôvárkony is still ambiguous. Although Fülöp (in Hetényi et al. 1968) indicated a Late Valanginian age, Bujtor (2011) reported that the deposition of the iron ore formation may have started in the Early Valanginian $T$. pertransiens Zone. The belemnites (Gillieronibelus? sp.) from the ore and the covering marl beds at Zengóvárkony indicate a younger age, namely the Early Hauterivian (Bujtor et al. 2013). For the moment, it seems plausible that the age of the iron ore deposit is Late Valanginian to Early Hauterivian. 


\section{Studied sections}

Two sections were investigated and described in this study (Figs 1 and 3). These sections are located in valleys surrounding the former ore mine (Dezsô Rezsô and Bolondút Valleys); they traverse the volcano-sedimentary succession and also expose the ore deposit, the volcanites, and the sedimentary succession.

\section{Dezső Rezső Valley section}

This outcrop is described in detail by Bujtor (2006, 2007, 2011, 2012a, 2012b) and by Bujtor et al. (2013); it is situated along the northwestern slope of the valley (Fig. 4). It also provided loose blocks and fragments of hydrothermal sediments and minerals (calcite, quartz, and amethyst) from the floor of the Dezső Rezsô Valley close to its southeastern end, facing toward Pusztakisfalu.

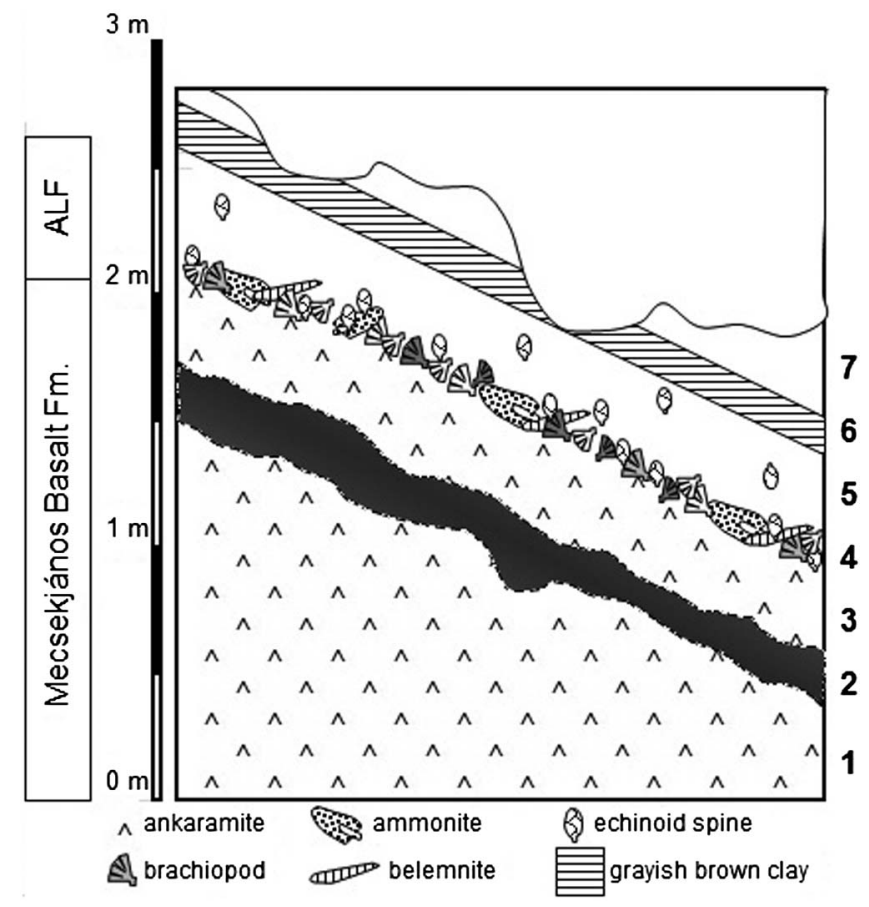

Fig. 4

The Dezső Rezső Valley NW section modified after Bujtor (2006, 2007) and Bujtor et al. (2013). 1 and 3 : fully altered ankaramite pillow basalt; 2 : intercalated and impregnated limestone bed; 4: fossil-rich limestone bed with allochthonous fauna; 5: brownish-yellow-colored massive limestone bed with rare echinoid spines and brachiopod half valves, but with a monotypic Favreina crustacean isp.; and 6: brown-colored clay bed. ALF: Apátvarasd Limestone Formation 
The outcrop is situated south of the E65 main road. It traverses the Mecsekjános Basalt Formation and the basal Apátvarasd Limestone Formation. The lower part of the section exposes the fully altered volcanic pillow lava and hyaloclastite version of the Mecsekjános Basalt Fm. A submarine origin is revealed by vesicles (1-6 mm in diameter) in the chilled margin of the pillows. A fossiliferous limestone bed rests concordantly upon the volcanic surface and alternates with the iron ore beds. The locality yielded large but fragmentary allochthonous phylloceratid and lytoceratid ammonites (Lytoceras subfimbriatum; cf. Bujtor 2012b), belemnite rostra (Bujtor et al. 2013), a rich and almost monotypic brachiopod assemblage (Bujtor 2006, 2011, 2012b), echinoid spines (Bujtor 2012b), and some internal molds of poorly preserved gastropods. Thin sections of the ammonite body chambers reveal microfaunal elements, such as foraminifera, echinoderm remains, sponge spicules, and rarely crustacean microcoprolites. The metasomatized limestone bed (Bed 2 in Fig. 4) provided a rich foraminifera assemblage.

\section{Bolondút Valley section}

The section is situated on the western flank of the Bolondút valley (Fig. 5), south of the viaduct of the E65 main road, described by Bujtor (2012a, 2012b). The outcrop exposes the basal beds of the Apátvarasd Limestone Formation, a redcolored unstratified limestone block without macrofauna. The limestone block is traversed by fractures and is considered a tectonically uplifted block. The limestone is partly metasomatized and commonly penetrated by white, thin calcite veins. It rarely contains patches of goethite. In thin sections, the microfaunal elements consist of abundant crustacean microcoprolites, among which $P$. decaochetarius,

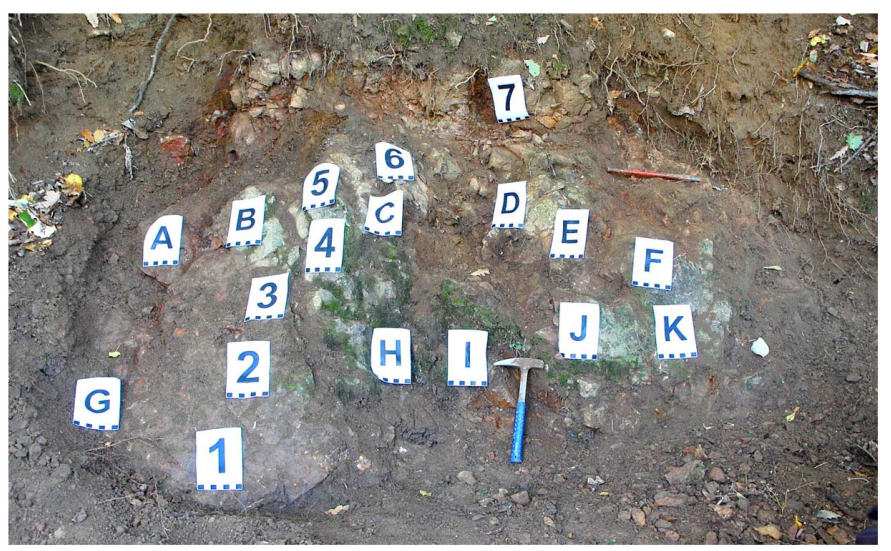

Fig. 5

The Bolondút Valley section. This is considered to be a tiny uplifted block that provided a rich microfauna. Numbers and alphabets refer to the sampling points for thin sections 
$P$. tetraochetarius, and $F$. hexaochetarius predominate. Other crustacean microcoprolite ichnospecies, foraminifera, sponge spicules, and shell fragments of brachiopods are accessorial elements of the fauna. The blocky structure of this uplifted rock body is also revealed by the incidental accumulation and presence of crustacean microcoprolites at sample points. The rock-forming occurrences of coprolites are concentrated at the southern part of the uplifted block (sample points A, B, G, and $2,5)$, whereas remaining sample points provided no microfauna or rare occurrences of some microfossils.

\section{Materials and methods}

Thin sections were prepared by Mr. Ferenc Budai (Hungarian Geological and Geophysical Institute, Budapest, Hungary) and by us. Based on the thin-section evaluation, some rock samples were selected for dissolving processes. These samples were treated according to the methods of Lethiers and Crasquin-Soleau (1988), being dissolved in concentrated acetic acid and then washed. Residual samples were investigated under reflected light of a Zeiss stereo microscope. The thin sections are housed in the Hungarian Natural History Museum (Ludovika tér 2-6, Budapest H-1083, Hungary) with the original rock samples. Due to the fact that the described crustacean ichnospecies are circular or subcircular in cross section (cf. Blau 2000), the individual axial ( $\mathrm{D}_{\mathrm{A}}$ : along symmetry plane) and horizontal $\left(\mathrm{D}_{\mathrm{H}}\right.$ : perpendicular to the symmetry plane) dimensions of each coprolite from thin sections were measured and provided the basis for data analysis. Consequently, the measurements of oblique microcoprolite sections were not considered for the statistical analysis.

\section{Results}

This study is the first analysis of the microfauna of the iron ore deposit and related lithofacies. The results are introduced in the following sequence: age of the deposits, faunal results based on thin-section observations, additional data based on the analysis of residual dissolution material, and statistical analysis of measured microcoprolite data. Finally, a synthesis of the fossil assemblages is provided.

\section{Age of the deposits}

There are major uncertainties regarding the age and correlations of the reported sections. Only the NW Dezsô Rezsô Valley section provided stratigraphically important fossils. Based on the belemnites and dinoflagellates, it has been dated as Late Valanginian-Early Hauterivian. The Bolondút Valley section has not provided stratigraphically useful fossils. It may represent the time spans from uppermost Berriasian to the Lower Hauterivian, because the upper part of the 
Apátvarasd Limestone Fm has neither metasomatized members nor calcite veins nor iron ore bodies.

\section{The microfauna}

The investigated thin sections point to similar microfacies and paleontological backgrounds. The most significant, but still minor, difference between microfacies is the amount of the allochemical components in thin sections. The sample that provided the richest microfauna comes from Bed 2, Dezsô Rezsô Valley (Fig. 4), which is a biomicritic wackestone and rarely a packstone-textured limestone. The micritic but rarely microsparitic matrix contains various sized allochemical components with prevailing bioclasts (Fig. 6e). The limestone is frequently impregnated with ferrigenous material. It is also thoroughly penetrated by thinner or thicker white calcite veins, which probably belong to several generations of calcites with different growing directions. The many and thick veins give the rock sample a breccia-like appearance in thin section. The most abundant bioclasts in the thin sections (Fig. 6f) are the sponge skeletal fragments and spicules, but echinoderm and mollusk skeletal fragments, foraminifera, and ostracod remains are also present. A few macrofaunal elements of ammonites, belemnite rostra, and brachiopods (Fig. 6e) are also observed. Traces of frequent bioerosion are typical for these fragments.

Foraminifera. Only a limited number of poorly preserved foraminifera specimens were able to be extracted from the host limestone sediments. Therefore, the determination of the foraminifer taxa was based only on thin-section observations. In thin section, both benthic and planktonic foraminifer taxa are recognized. The determined benthic taxa are the following in decreasing abundance: Glomospira sp. [Fig. 6a and b; most probably Glomospira cf. gordialis (Jones and Parker 1860)], Lenticulina sp., Spirillina sp. (Fig. 6d), Nodosaria sp., Epistomina sp., Trocholina sp., and other textulariid forms. Among the planktonic foraminifera, some regular, spherical, low trochospiral coiling-mode chambers prevail. The last chamber is always much bigger than the earlier ones. Chamber walls are thin without visible perforations. This form most probably belongs to Hedbergella sp. (Fig. 6c).

Sponges. One of the most interesting finds are sponge spicules that are not previously reported. There are spicules both in the thin sections and in dissolved material. Most probably, the original material of the sponge spicule fragments was silica. There are singular spicules or spicule fragments connected to skeletons. The most abundant sponge spicules are a diactine-type criccorhabds (Fig. 6g-i) and an anactine-type rhax (Fig. 6j) forms. These fragments of sponges occur in some cases in rock-forming quantity. Preservation of the spicules is variable. Some sponge spicules are well preserved, which may indicate low-energy bottom currents and a calm sedimentary environment. Some of the sponge remains can be associated with lithistid demospongiae (Fig. 6k-o). However, the criccorhabds in our material have no recent equivalents; therefore, their environmental demands are not known. Only lithistids have recent equivalents but with wide ecological requirements (A. Pisera, personal 


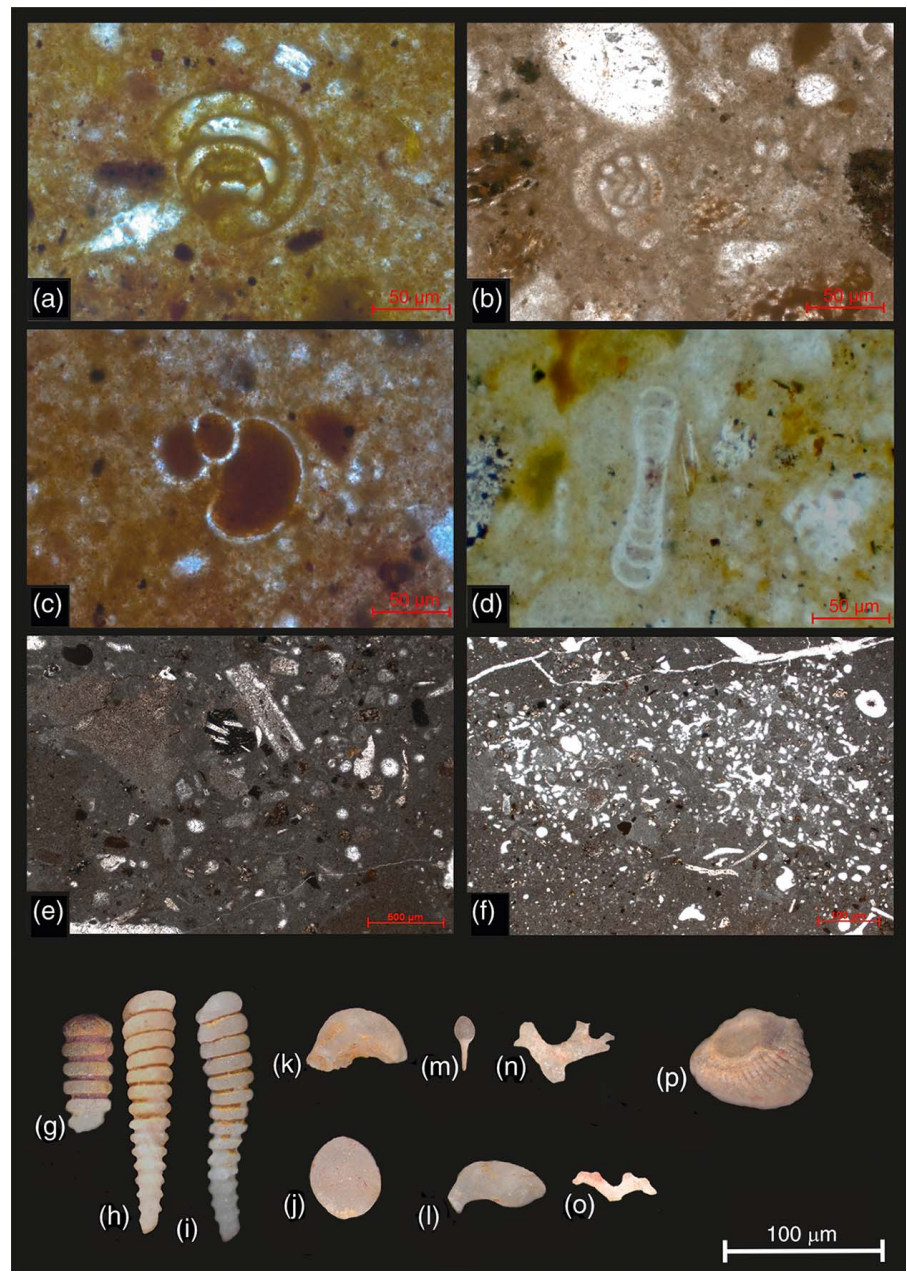

Fig. 6

(a and b) Glomospira sp. cf. gordialis from thin section. Scale bar indicates $100 \mu \mathrm{m}$. Sample from the Dezső Rezső Valley section, Bed 2, Zengővárkony. (c) Hedbergella sp. from thin section. Scale bar indicates $100 \mu \mathrm{m}$. Sample from the Dezső Rezső Valley section, Bed 2, Zengóvárkony. (d) Spirillina sp. from thin section. Scale bar indicates $100 \mu \mathrm{m}$. Sample from the Dezső Rezső Valley, Zengővárkony section, Bed 4, body chamber of a Lytoceras sp. (e) Biomicritic packstone-textured limestone with different allochemical components (sponge spicules, foraminifer fragments, and echinoderm fragments) and volcanite extraclasts. Scale bar indicates $100 \mu \mathrm{m}$. Sample from the Dezső Rezső Valley section, Bed 2, Zengôvárkony. (f) Lithistid sponge skeleton (megaclones) in biomicritic limestone. Scale bar indicates $100 \mu \mathrm{m}$. Sample from the Dezső Rezsô Valley section, Bed 2, Zengővárkony. (g-i) Diactine-type criccorhabd sponge spicules from residual material of dissolved rock samples. Scale bar indicates $100 \mu \mathrm{m}$. Sample from the Dezsô Rezső Valley section, Bed 2, Zengôvárkony. (j) Rhax sponge spicule from residual material of dissolved rock sample. Scale bar indicates $100 \mu \mathrm{m}$. Sample from the Dezső Rezső Valley section, Bed 2, Zengôvárkony. (k-o) Undetermined sponge spicules from the residual material of dissolved rock samples. Scale bar indicates $100 \mu \mathrm{m}$. Sample from the Dezsô Rezsô Valley section, Bed 2, Zengővárkony. (p) Fragment of a hexactinosan skeleton from thin section. Scale bar indicates $100 \mu \mathrm{m}$. Sample from the Bolondút Valley section, Zengővárkony, (e), sampling point " 5 " 
communication, 2014); thus, further debate is problematic. From thin sections, a badly preserved fragment of a hexactinosan sponge skeleton was also revealed (Fig. 6p).

Crustacean microcoprolites. The two sites provided a rich crustacean microcoprolite ichnofauna (Bujtor 2012a). Jáger et al. (2012) also added previously unknown microcoprolite taxa, probably of the same age, from the other parts of the Mecsek Mts. This specific diversity is combined with the individual richness of some microcoprolite ichnospecies. The mass occurrences of crustacean microcoprolites are concentrated on the species of $F$. hexaochetarius, $P$. tetraochetarius, and $P$. decaochetarius, as the previous authors (Pantó et al. 1955; Palik 1965; Bujtor 2012a) already noted. The size distributions of the crustacean microcoprolite assemblages point to an environment where their producers may have been continuously present from juvenile to adult stages. Data analyses were carried out on statistically important species.

$F$. hexaochetarius. Based on two specimens, Palik (1965) introduced this species as line drawings from thin sections. Diameters of the type material vary between 260 and $360 \mu \mathrm{m}$ (Palik 1965). Since its first description, no other records were published on this ichnospecies. The present material (Fig. 7) provided 40 specimens and a wider range of dimensions, from 125 to $400 \mu \mathrm{m}$. The average diameter is $260 \mu \mathrm{m}$. This ichnospecies is associated with $P$. tetraochetarius. No intraspecific variability was observed on this species.

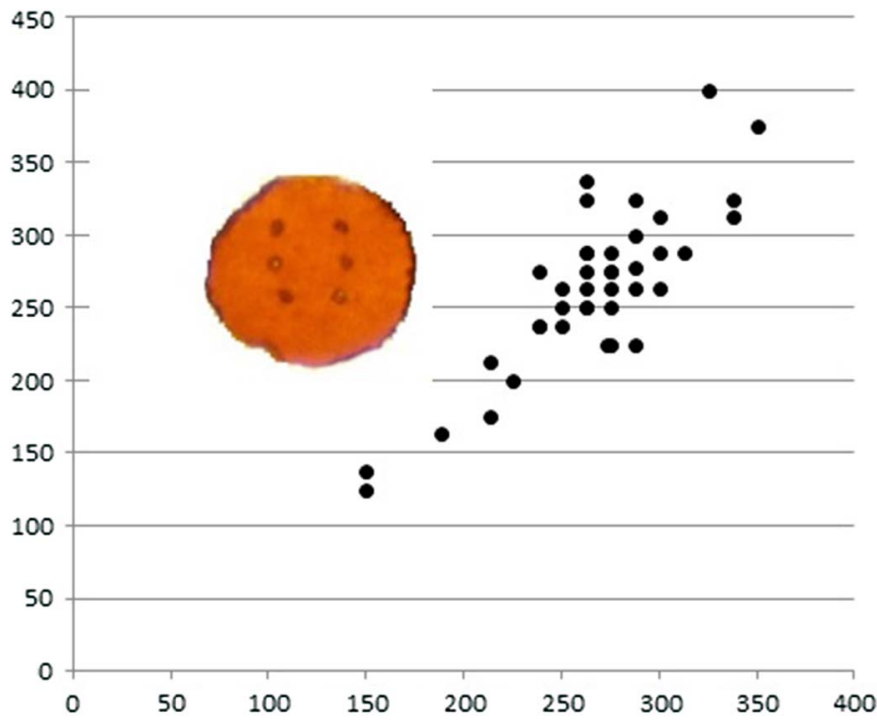

Fig. 7

Size distribution of Favreina hexaochetarius. All samples came from the Bolondút locality, sample points A, B, G, and 5 (see Fig. 5 for spatial distribution of sample points). $n=40$. Horizontal $\left(\mathrm{D}_{\mathrm{H}}\right)$ and vertical $\left(\mathrm{D}_{\mathrm{A}}\right)$ axes scales are in $\mu \mathrm{m}$ 
P. tetraochetarius. This ichnospecies was introduced based upon photographs and line drawings of 14 specimens from thin sections. Earlier, Pantó et al. (1955) reported these fossils as "microorganisms," being the most abundant microfossils in the iron ore. Palik (1965) also supported this observation. The type material has a wide range of dimensions, from 92 to $420 \mu \mathrm{m}$ (Palik 1965). Based on the present material, 243 specimens were measured (Fig. 8). This material provided a complete series of coprolite stages from 115 to $550 \mu \mathrm{m}$, while the average diameter is $280 \mu \mathrm{m}$. The material is associated with $F$. hexaochetarius and $P$. decaochetarius but never cooccurs with $F$. belandoi or $P$. triochetarius. Intraspecific variation of bending of ventral canals is present. When the ventral canals show slight bending, the specimens of $P$. tetraochetarius are almost impossible to distinguish from Palaxius osaensis (Buchs et al. 2009), as Bujtor (2012a) already discussed.

P. decaochetarius. Palik (1965) introduced this species with photographs and line drawings of two specimens. Size distribution of the type ichnospecies (Palik 1965) varies between 700 and $840 \mu \mathrm{m}$. Bujtor (2012a) enlarged the size distribution from 470 to $1,060 \mu \mathrm{m}$ based on 16 specimens and described the intraspecific variety and ontogeny (Bujtor 2012a) of this isp. P. decaochetarius is also reported from the Upper Tithonian-Lower Berriasian of the Neuquén Basin, Argentina (Kietzmann et al. 2010). The present analysis is based on 39 specimens (Fig. 9) and further stretched

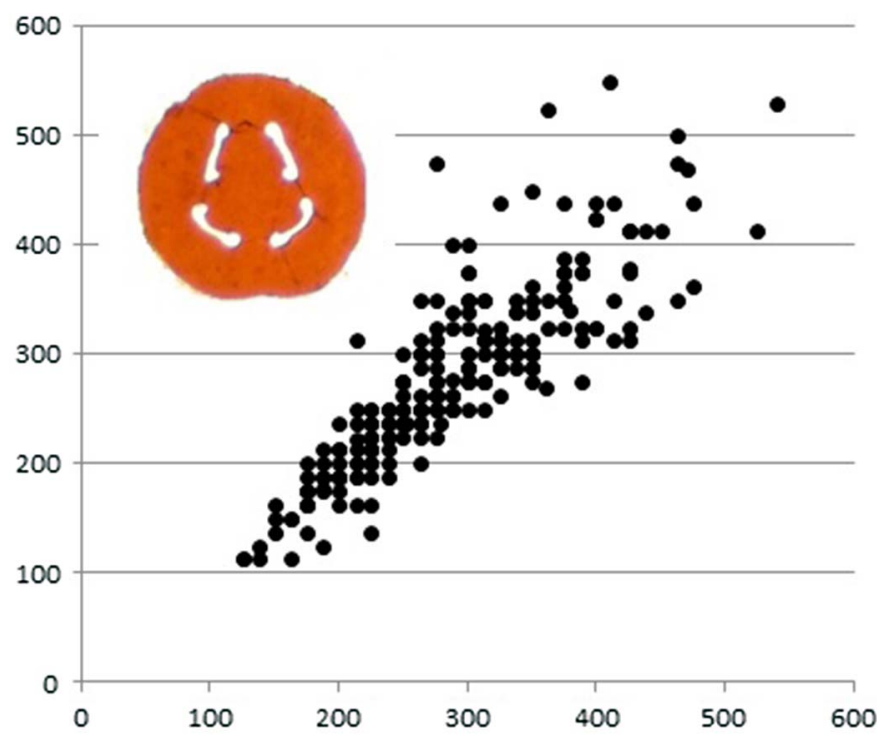

Fig. 8

Size distribution of Palaxius tetraochetarius. All samples came from the Bolondút locality, sample points A, B, E, and G (see Fig. 5 for spatial distribution of sample points). $n=243$. Horizontal $\left(D_{H}\right)$ and vertical $\left(D_{A}\right)$ axes scales are in $\mu \mathrm{m}$ 


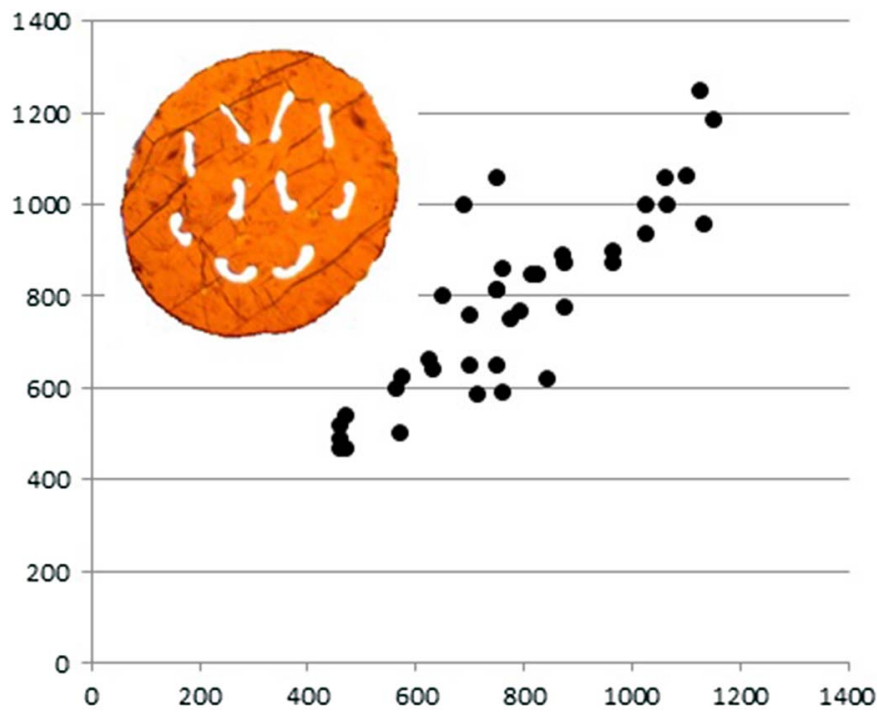

Fig. 9

Size distribution of Palaxius decaochetarius. All samples came from the Bolondút locality, sample points A, E, F, I, J, 2, 5, and 7 (see Fig. 5 for spatial distribution of sample points). $n=39$. Horizontal $\left(\mathrm{D}_{\mathrm{H}}\right)$ and vertical $\left(D_{\mathrm{A}}\right)$ axes scales are in $\mu \mathrm{m}$

the range of dimension of this ichnospecies from 460 to $1,150 \mu \mathrm{m}$. The average diameter is $780 \mu \mathrm{m}$.

Echinoderms. Echinoderms around the hydrothermal center are already reported as macrofossils (Szörényi 1961, 1965; Bujtor 2012b, 2013b); however, this is the first record of echinoderm remains from residual material of dissolved rock samples. An undetermined crinoid fragment (Fig. 6p) may also indicate a diverse sea-bottom fauna farther from the hydrothermal activity.

\section{Description of microfaunal assemblages}

Based on the microfacies analyses, different types of microfossil assemblages were recognized. These assemblages are different in their fossil content and supposed spatial distribution from the bottom hydrothermal activities.

Glomospira-dominated foraminifer assemblage. The recognition of Glomospira cf. gordialis is a very important element in identifying the possible environment of this type, because this was the only foraminifer taxon found in a contaminated carbonate bed. This foraminifer is reported from Bed 2 of the NW section, Dezsô Rezsô Valley. This bed is a metasomatized limestone bed impregnated by ferrigenous solutions, which points to the close vicinity of the hydrothermal sea-bottom activity. Based on recent analogs (Panieri et al. 2005), this environment may have been the closest to the hydrothermal activity zone. 
Diverse, Palaxius-dominated assemblage. The crustacean coprolites occur in rock-forming quantities and reveal a diverse microcoprolite fauna dominated by $P$. decaochetarius, $P$. tetraochetarius, and $F$. hexaochetarius. This assemblage is composed almost exclusively of coprolites. The host rock is partly metasomatized, which indicates proximity to the hydrothermal zone.

Monotypical, Favreina-dominated assemblage. This monotypic assemblage is dominated by the immense quantities of $F$. belandoi (Fig. 10a and b) and is considered a heteropic biofacies to the Palaxius and foraminifer-dominated assemblages. It occurs in Bed 5 of the Dezsô Rezsô Valley section (Fig. 4), where F. belandoi appears in huge quantities; however, no other macro- or microfossils are preserved. At other localities of the Mecsek Mts., Jáger et al. (2012) also reported F. belandoi almost monotypically or together with the dubious presence of $P$. decaochetarius (Jáger et al. 2012). This observation strengthens the assumption that the animal producing $F$. belando $i$ preferred soft substrate around or away from the hydrothermal zones, but never lived directly in those zones.

Diverse, sponge-dominated assemblage. The sponge fauna is less diverse. It contains remnants of lithistid, non-lithistid demospongiae, and hexactinosan sponges (A. Pisera, personal communication, 2014). It provides an important contribution to the faunal buildup of this environment. This conclusion is an important one and documents that in the geologic past, sponges were also present in the vicinity of the hydrothermal zones, as they are already reported from recent hydrothermal vents

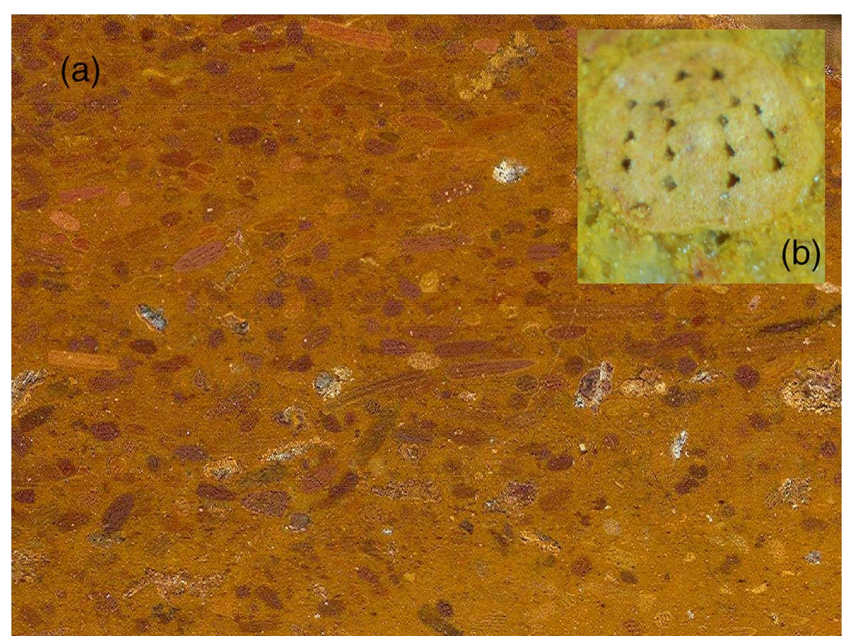

Fig. 10

(a-b) Mass occurrence of Favreina belandoi from Bed 5, Dezső Rezsô Valley NW section, limestone bed. (a) Unsorted mass occurrence of monotypic crustacean microcoprolites. Height of the figure is $7 \mathrm{~cm}$. (b) Close view of a transversal section of a polished limestone sample with Favreina belandoi isp., juvenile growth stage (cf. Schweigert et al. 1997; Fig. 10). Diameter of the coprolite in the insert is $400 \mu \mathrm{m}$ 
(Vacelet 2006). This assemblage also contains echinoderm microfossils, which is in line with the earlier observation on the echinoderm macrofauna at this site (Szörényi 1961, 1965; Bujtor 2012b).

\section{Discussion}

The Zengóvárkony seafloor hydrothermal exhalation system was developed on continental crust, which as yet has no known recent or fossil analogs. In order to understand the spatial distribution of the reported foraminifera in our material, we use the distribution pattern of recent foraminifera in similar environments.

Regarding the spatial distribution of foraminifera from recent hydrothermal environments, Panieri et al. (2005) recognized three different foraminifer assemblages situated at different distances from the center of the hydrothermal activity. The most distant assemblage from the hydrothermal activity center, indicating a seagrass environment, is characterized by Lobatula lobatula (Walker and Jacob 1798), Asterigerinata mamilla (Williamson 1858), Rosalina globularis (d'Orbigny 1826), and Quinqueloculina spp. as main constituents. Closer to the center, the second assemblage is characterized by the abundant quantity of Ammodiscus catinus (Höglund 1947), Ammoglobigerina globigeriniformis (Parker and Jones 1865), Glomospira gordialis (Jones and Parker 1860), and Haplophragmoides canariensis (d'Orbigny 1839), which suggests low $\mathrm{pH}$ conditions resulting from acidic hydrothermal emissions. This leads to the dissolution of calcium carbonate tests. Closest to the hydrothermal exhalations, the third assemblage is characterized by A. catinus, Glomospira charoides (Jones and Parker 1860), and G. gordialis and indicates direct hydrothermal influences. In our material, the specimens of Glomospira sp. (Glomospira cf. gordialis) are the most abundant foraminifer taxon, which points to the latter two assemblages of Panieri et al. (2005) and may be indicative of the close vicinity of the hydrothermal activity center. This conclusion is also supported by the lithology of the host rock samples. It was penetrated by ferruginous solutions and shows contamination in the form of the fully altered basaltic rocks (Fig. 11). This evidence and its positive correlation to the characteristics of the available environments reported by Jonasson et al. (1995), Panieri et al. (2005), and Karlen et al. (2010) strongly support the recognition of a fossil microfaunal assemblage in our material close to the hydrothermal center and under its direct influence. The observation that agglutinated forms do not prevail over the calcareous ones may point to moderate $\mathrm{pH}$ conditions, in that the hydrothermal fluids were not acidic enough to dissolve the calcareous tests. Not only benthic but planktonic foraminifers were also recognized in our samples (Fig. 6c). Diversification of the planktonic foraminifera had begun after the Valanginian. For this reason, there are very limited records on planktonic foraminifera from the Valanginian or earlier (BouDagher-Fadel et al. 1997). Therefore, despite relatively good preservation of the planktonic foraminifera in our material, their specific determination was not possible. 


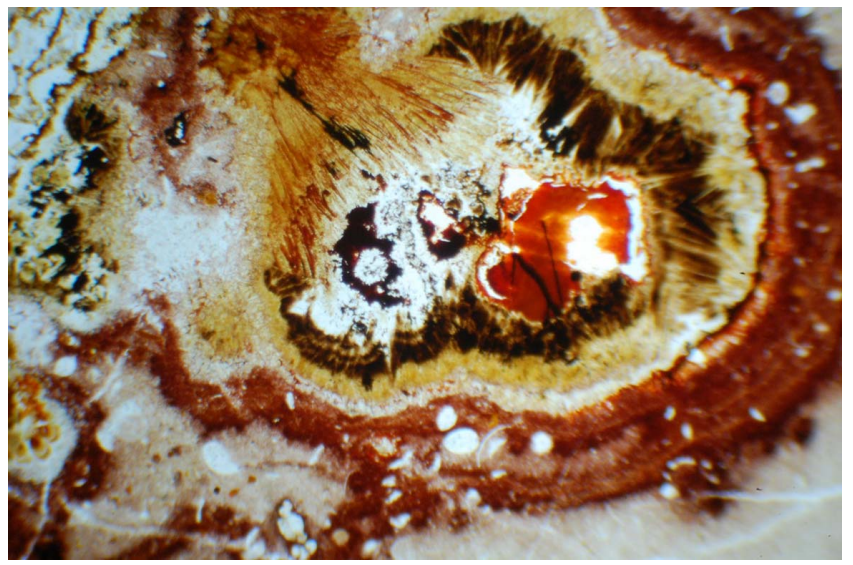

Fig. 11

Contaminated limestone sample from Bed 2 of the Dezső Rezső Valley section, Zengôvárkony. It shows the contact zone of the limestone and the basaltic rocks

Reconstruction of the depositional environments based on microfaunal assemblages

The Zengóvárkony hydrothermal center was developed within a continental rift region (Bilik 1983; Harangi 1994) covered by significantly thick soft sediments. However, regarding the sessile organisms requiring hard substrates (brachiopods in the Mesozoic and the Recent bivalves), the Zengóvárkony iron ore-related hydrothermal center is similar to that of the recent setup of hydrothermal vent faunas, as Tokeshi (2011) reported. There are indications that at recent shallow marine hydrothermal vents, brachiopods appear close to the vents (Morri et al. 1999). In contrast, at Zengővárkony, the presence of the rock-forming quantity of crustacean microcoprolites implies a burrowing mode of life of the host animals (Pohl 1946; Felgenhauer 1992; Dworschak et al. 2012), which requires soft substrates to build their burrows. The simultaneous presence of hard and soft substrates at Zengővárkony is proven; it offered biotopes for both epifaunal and burrowing decapods. Rifting had begun in continental crust, in a hemipelagic basin where partly or non-consolidated sediments were present; they may have been there longer when the pillows appeared on the sea floor. A similar recent environment of soft substrate and its related bacterial and crustacean fauna is reported from Greece. Sievert et al. (1999) reported the spatial distribution of bacterial populations and related macrofauna in and around a shallow marine vent site from Milos Island (Aegean Sea). At the center of the hydrothermal activities, bacterial mats are observed on the seafloor (Aliani et al. 1998; Sievert et al. 1999) in high diversity (Davis and Moyer 2008). At Zengóvárkony, negative sulfur stable isotope values are recorded, which may indicate biogenic (bacterial?) activity at or around the hydrothermal centers. However, the origin of the considerable negative sulfur isotope data needs further investigation. 
In the close vicinity of the hydrothermal activities, environmental conditions were not ideal for benthic foraminifera, except for Glomospira sp. (G. cf. gordialis), which is the most characteristic vent foraminifer taxon (Panieri et al. 2005). From a similar water depth as that in which the Zengóvárkony iron ore was deposited (150-200 m), Sarano et al. (1989) already reported a hydrothermal vent structure 10-30 m away from soft sediments, with holes and mounds possibly belong to Callianassa. This recent analog helps understand the remarkable richness of crustacean ichnofauna here. Continental rifting and its resulting intrusive magmatic bodies as a geotectonic framework are necessary and convincing, where the magma bodies traversed fully or partially consolidated sediments; outflow on the seafloor of the partially or unconsolidated sediments produced mixed volcano-sedimentary rocks (Harangi 1989), such as peperites (Jáger et al. 2012), and built-up generations of minerals (calcite, quartz, and amethyst) in the pillow basalts on the Tithonian-Berriasian sediments. Callianassa mounds (tiny swells around the entrance of crab burrows on the sea bottom) are situated close to the center of the recent shallow-marine hydrothermal centers. As Sievert et al. (1999) recognized, they appear only at around $2 \mathrm{~m}$ from the center of the hydrothermal activity, where their mounds are the densest. Further from the center, the number of the Callianassa mounds decreases. The possible host animal of the Palaxius-like coprolites was already referred to as Callianassa by Pohl (1946), an assumption which was strengthened by anatomical (Felgenhauer 1992) and ecological (Dworschak et al. 2012) records as well. Fossil evidence for the host animal of Palaxius microcroprolites is reported by Peckmann et al. (2007) from the Eocene cold seep, where a callianassid body fossil was preserved together with a Palaxius microcoprolite.

The necessary soft substrate and the required bacterial mats as primary food resource for the shrimps were present at Zengóvárkony. The hydrothermal minerals are situated between the pillows; however, there were also interpillow soft sediments, which could have provided the ecological niches for the burrowing callianassid shrimps that had left the microcoprolites. The rock-forming quantities of microcoprolites indicate the ideal conditions for their producers. This scenario is supported by recent observations: callianassid mud shrimps prefer the vicinity of hydrothermal fields and exhalations, as Panieri et al. (2005) and Karlen et al. (2010) have demonstrated.

Brachiopods may have anchored on the hard substrates provided by the pillows, as Stewart (1981) reported in the case of the recent Terebratella species.

Echinoderms are rare at recent deep-sea hydrothermal vents, representing only $0.1 \%$ of the total number of vent-related species (Wolff 2005), but are abundant in shallow-marine hydrothermal vent fields (Zhirmunsky and Tarasov 1990) where Strongylocentrotus live at 2-5 m water depth in huge quantities. In deeper environments, sea urchins (Echinus) were reported by Van Dover et al. (1996) from 1,650 m water depth. Recently, Gaillard et al. (2011) reported a monospecific echinoid assemblage (Tithonia oxfordiana; Gaillard et al. 2011) from a fossil hydrocarbon seep carbonate in southeastern France. These observations create that ecologic 
framework in which the abundant echinoderm micro- and macrofauna of the Zengővárkony vent site will be understood. Echinoid spines are well known and frequent at Zengővárkony (Szörényi 1961, 1965; Bujtor 2006, 2012b) and they frequently appear in thin sections of the Bolondút locality. The well-preserved echinoid spines belong to Cidaris cherennensis (Savin 1905), Balanocidaris rysacantha (Gras 1848), and Pseudocidaris clunifera (Agassiz 1836). Recently, Bujtor (2013b) reported an echinoderm body fossil (Plegiocidaris sp. ind.) from the floor of the Dezső Rezsô Valley. Probably, these echinoids played the same role in this fossil environment as the $T$. oxfordiana did in that seep carbonate reported from France. Crinoids were also reported by early researchers (Szörényi 1961, 1965; Fülöp in Hetényi et al. 1968) and they referred to a Torynocrinus species of a cliff-living habitat. This study did not confirm these findings. However, the undetermined echinoderm skeletal fragment (Fig. 6p) provides further clues.

\section{Around the hydrothermal centers}

Distribution of the sponge spicules in paleoenvironments is diverse. They are reported from shallow to outer shelf as well as bathyal settings. Some specialized forms are even reported from unique environs indicating extreme conditions, such as the vent/seep environments. Unfortunately, only a handful of papers focus on the presence of sponges in hydrothermal vent environments. Although Jochum et al. (2009) reported sponge spicules that were under hydrothermal fluid impact, there is no evidence that sponges live at or near vents yet. The lithistid sponge remains belonging to the family Pleromidae are the most common in our material; they occur today at water depths of 300-800 m (Hooper and Van Soest 2002). According to the opinion of the present authors, they have lived farthest from the vent center, at or around the rim of the uplifted block on which the venting occurred.

\section{Bathymetric speculations}

The quantity of the planktonic and benthic foraminifers is equal. This points to a relatively shallow marine environment with open marine connection. This observation is in line with the previous bathymetric speculations and data (Bujtor 2006, 2007; Jáger and Molnár 2009) and supports the assumption that the vent site was at around 100-300 m water depth. All benthic foraminifera are poorly preserved and small-sized (around $100 \mu \mathrm{m}$ ), whereas the planktonic forms are well preserved and large-sized.

\section{Concurrent interpretations}

Jáger et al. (2012) criticized the concept of vent-related crustaceans at Zengövárkony, although Jáger (2008) and Jáger and Molnár (2009) were the first to report the black smoker chimneys, later rejecting the hydrothermal vent origin and instead 
proposing a wood-fall-based ecosystem. To understand the mode of life and the unique diversity and richness of the decapod crustacean ichnospecies of the vent site, the diet and feeding ecology of decapod crustaceans must be considered. Hoyoux et al. (2009) reported that recent galatheid crabs (truly original detritivorous species) changed their diet from detritus feeder to wood eater in a depth range of $150-1,000 \mathrm{~m}$. This is a very important observation because crustaceans constitute the second largest zoological group in deep-sea wood falls, with many species of decapods (galatheid squat lobsters, pagurid hermit crabs, and thalassinid shrimps). Similarities between the cross sections of the recent and fossil crustacean excrements are remarkable (cf. Felgenhauer 1992; Fig. 10b and Schweigert et al. 1997; Fig. 7d-f). Therefore, Schweigert et al. (1997) warned that "the evolution of the gross morphology of the decapods is much more diverse and rapid than that of the digestive tract, which is rather conservative. Therefore, microcoprolites only allow to distinguish different families of producing crustaceans but a separation on the biospecies level seems rather impossible." Most probably, those ichnospecies that are abundant and rock-forming at Zengóvárkony are closely related to the hydrothermal centers and surely belong to the Pleocyemata suborder of decapod crustaceans. Their mode of life was filter-feeding and they lived in burrows in soft sediments around the hydrothermal centers. Most probably, they were bacteria eaters. Therefore, it is possible that those host animals that left similar microcoprolites at wood-fall environments represent different biological species than those ones that left the same microcoprolite ichnospecies at Zengóvárkony. Those crustaceans that belong to wood-fall communities may eat wood and leave the same microcoprolites as those that feed on bacteria and live around the hydrothermal seabottom centers. Their taxonomical separation based on their microcoprolites is impossible; however, they may represent different biological species.

\section{Conclusions}

Faunas of the recent shallow marine vent sites are atypical compared to those of the "classic" deep-sea hydrothermal vents. This phenomenon is more pronounced in the case of fossil shallow marine vent sites. These formations are rare and if fossilized, they contain poor fauna. Therefore, the Valanginian-Hauterivian shallow marine vent site of Zengóvárkony (Mecsek Mts., Hungary) is of special importance for understanding these marine hydrothermal vent settings. It provided a relatively rich microfauna of different taxa of sponges, foraminifera, crustacean microcoprolites, and echinoderms. Four different iron ore-related microfaunal assemblages were recognized around the former hydrothermal centers. The hydrothermal sediments close to the hydrothermal center are characterized by Glomospira sp. In the surrounding soft sediments, diverse burrowing decapod crustaceans lived. Farthest from the venting were the lithistid demospongiae; an undetermined echinoderm community is supposed, based on echinoderm skeletal remains, echinoid spines and rarely, echinoid body fossils. 
Although the recorded microfossils did not provide stratigraphically important forms, the reported assemblage strengthens the previous results on the water depth and the paleoenvironment of the hydrothermal site. This is the first record of microfossil assemblages from a fossil shallow marine hydrothermal activity center site developed on continental crust.

\section{Acknowledgements}

The authors would like to thank the useful remarks and critical comments of Steffen Kiel and Andrzej Pisera on the early version of this paper. They would also like to thank Ferenc Budai for preparing the thin sections. The authors are grateful to Ágnes Görög for the consultations on the foraminifer investigations. LB enjoyed the financial support of the Bolyai János Research Grant of the Hungarian Academy of Sciences during this research. The authors would also like to thank Krzysztof Hryniewicz and the anonymous Hungarian reviewer for their comments that significantly improved the quality of this paper.

\section{References}

Agassiz, L. 1836: Notice sur les fossils du terrain Crétacé du Jura Neuchatelois, 1835 [Notes on the fossils from the Cretaceous terrains of the Jura at Neuchatel]. - Mémoires de la Société Scientiennes de Neuchatel, 1, 150 p.

Aliani, S., C.N. Bianchi, S. Cocito, P.R. Dando, R. Meloni, C. Morri, A. NieMeyer, A. Peirano, W. Ziebis 1998: A map of seagrass meadows in Palaeochori Bay (Milos Island, Greece), a marine area with hydrothermal activity. - Rapports et Procès Verbaux des Réunions Commission internationale pour l'Éxploration Scientifique de la Mer Méditerranéenne, 35, pp. 512-513.

Bilik, I. 1974: Unterkretazische Vulkanite des Mecsek-Gebirges [Lower Cretaceous volcanites of the Mecsek Mountains]. - Acta Geologica Academiae Scientiarium Hungaricae, 18/3-4, pp. 315-325.

Bilik, I. 1983: Lower Cretaceous submarine (rift) volcanism in South Transdanubia (South Hungary). - In: Bisztricsány, E., Gy. Szeidovitz (Eds): Proceedings of the 17th Assembly of the European Seismological Committee. Akadémiai Kiadó, Budapest, pp. 569-576.

Blau, J. 2000: FAVRIS - The interactive database on structured crustacean coprolites. - https://www.staff. uni-giessen.de/ gg13/FAVRIS/FAVRIS.HTM.

BouDagher-Fadel, M.K., F.T. Banner, J.E. Whittaker 1997: Early evolutionary history of planktonic Foraminifera. - British Micropalaeontological Society, Publication series, Chapman \& Hall, London, $12,269 \mathrm{p}$.

Brönnimann, P., P. Cros, L. Zaninetti 1972: New thalassinid anomuran (Crustacea, Decapoda) coprolites from infraliassic limestones of the Dolomites, Italy. - Mitteilungen der Gesellschaft der Geologie- und Bergbaustudenten in Wien, Wien, 21, pp. 921-928.

Buchs, D.M., J. Guex, J. Stucki, P.O. Baumgartner 2009: Paleocene Thalassinidea colonization in deep-sea environment and the coprolite Palaxius osaensis n. ichnosp. in Southern Costa Rica. - Revue de Micropaléontologie, 52, pp. 123-129.

Bujtor, L. 1993: Valanginian ammonite fauna from the Kisújbánya Basin (Mecsek Mts., South Hungary) and its palaeobiogeographical significance. - Neues Jahrbuch für Geologie und Paläontologie, Abhandlungen, 188/1, pp. 103-131.

Bujtor, L. 2006: Early Valanginian brachiopods from the Mecsek Mts. (southern Hungary) and their paleobiogeographical significance. - Neues Jahrbuch für Geologie und Paläontologie, Abhandlungen, 241, pp. 111-152. 
Bujtor, L. 2007: A unique Valanginian paleoenvironment at an iron-ore deposit near Zengóvárkony (Mecsek Mts., South Hungary) and a possible genetic model. - Central European Geology, 50, pp. 183-198.

Bujtor, L. 2011: The Early Valanginian ammonite, brachiopod and crustacean fauna of the Mecsek Mts. and its relationships with the embryonic shallow water hydrothermal vent at Zengôvárkony (Mecsek Mts., South Hungary). - Cretaceous Research, 32, pp. 565-574.

Bujtor, L. 2012a: A Valanginian crustacean microcoprolite ichnofauna from the shallow marine vent site of Zengővárkony (Mecsek Mts., Hungary). - Facies, 58, pp. 249-260.

Bujtor, L. 2012b: A mecseki alsó-kréta (valangini) hidrotermális hasadékrendszer őslénytani jellege [The palaeontological character of the Lower Cretaceous (Valanginian) hydrothermal vent filling of the Mecsek Mts., Hungary]. - Földtani Közlöny, 142/2, pp. 137-148. (in Hungarian)

Bujtor, L. 2013a: Valanginian perisphinctid ammonites from the Kisújbánya Basin (Mecsek Mts., Hungary). Cretaceous Research, 41, pp. 1-16.

Bujtor, L. 2013b: Kréta időszaki tengeri sün (Plegiocidaris) a Mecsekből [Cretaceous echinoid (Plegiocidaris) from the Mecsek Mts., Hungary]. - Földtani Közlöny, 143/4, pp. 321-326. (in Hungarian)

Bujtor, L., N.M.M. Janssen, R. Verreussel 2013: Early Cretaceous (Valanginian and Hauterivian) belemnites and organic-walled dinoflagellate cysts from a marine hydrothermal vent site and adjacent facies in the Mecsek Mts., Hungary. - Neues Jahrbuch für Geologie und Paläontologie, 269/2, pp. 135-148.

Callender, W.R., E.N. Powell 1992: Taphonomic signature of petroleum seep assemblages on the Louisiana upper continental slope: Recognition of autochthonous shell beds in the fossil record. - Palaios, 7, pp. $388-408$.

Császár, G. (Ed) 1996: Magyarország litosztratigráfiai alapegységei. Kréta [Lithostratigraphic Units of Hungary. Cretaceous]. - Geological Institute of Hungary, Budapest, 163 p. (in Hungarian)

Császár, G. 2002: Urgon Formations in Hungary with Special Reference to the Eastern Alps, the Western Carpathians and the Apuseni Mountains. - Geological Institute of Hungary, Budapest, Geologica Hungarica series Geologica, 25, 209 p.

Császár, G., D. Turnšek 1996: Vestiges of atoll-like formations in the Early Cretaceous of the Mecsek Mountains, Hungary. - Cretaceous Research, 17, pp. 419-442.

Csontos, L., A. Vörös 2004: Mesozoic plate tectonic reconstruction of the Carpathian region. - Palaeogeography, Palaeoclimatology, Palaeoecology, 210, pp. 1-56.

Davis, R.E., C.L. Moyer 2008: Extreme spatial and temporal variability of hydrothermal microbial mat communities along the Mariana Island Arc and southern Mariana back-arc system. - Journal of Geophysical Research, 113, pp. 1-17.

d'Orbigny, A.D. 1826: Tableau méthodique de la classe des Céphalopodes [Systematic description of the Class Cephalopoda]. - Annales des Sciences Naturelles, 7, pp. 245-314.

d'Orbigny, A.D. 1839: Les foraminifères des Iles Canaries [The Foraminifera of the Canary Islands]. - In: Parker-Webb, P., S. Berthelot (Eds): Histoire Naturelle des Iles Canaries, 2. Béthune, Paris, 574 p.

Dworschak, P.C., D.L. Felder, C.C. Tudge 2012: Infraorders Axiidea de Saint Laurent, 1979 and Gebiidea de Saint Laurent, 1979 (formerly known collectively as Thalassinidea). - In: Scham, F.R., J.C. von Vaupel-Klein (Eds): Treatise on Zoology - Anatomy, Taxonomy, Biology. The Crustacea, Vol. 9, Part B. Koninklijke Brill NV, Leiden, Boston, pp. 109-220.

Felgenhauer, B.E. 1992: Internal anatomy of the Decapoda: An overview. - In: Harrison, F.W., A.G. Humes (Eds): Microscopic Anatomy of Invertebrates, Volume 10: Decapod Crustacea. - Wiley-Liss Inc., New York, pp. 45-75.

Gaillard, C., C. Néraudeau, J. Thierry 2011: Tithonia oxfordiana, a new irregular echinoid associated with Jurassic seep deposits in south-east France. - Journal of Palaeontology, 54/4, pp. 735-752.

Gradstein, F., J. Ogg, A. Smith 2004: A Geologic Time Scale. - Cambridge University Press, Cambridge, 599 p.

Gras, A. 1848: Description des Oursins fossiles du Département de l'Isére [Description of the fossil sea urchins of the Isére region]. - Ch. Vellot et Comp., Grenoble, $120 \mathrm{p}$.

Harangi, Sz. 1989: Redeposited volcanoclastic limestone in the Eastern Mecsek Mts., southern Hungary. Acta Mineralogica-Petrographica, 29, pp. 81-93. 
Harangi, Sz. 1994: Geochemistry and petrogenesis of the Early Cretaceous continental rift-type volcanic rocks of the Mecsek Mountains, South Hungary. - Lithos, 33, pp. 303-321.

Hetényi, R., G. Hámor, I. Nagy 1968: Magyarázó a Mecsek hegység földtani térképéhez, 10.000-es sorozat, Apátvarasd [Explanations to the Geologic Map of the Mecsek Mts., ser. 10.000, Apátvarasd]. Geological Institute of Hungary, Budapest, 55 p. (in Hungarian)

Hooper, J.N.A., R.W.M. Van Soest 2002: Systema Porifera. A Guide to the Classification of Sponges. Kluwer Academic/Plenum Publishers, New York, 1810 p.

Horváth, A. 1968: Megfigyelések a Mecsek-hegység alsókréta rétegeiben (Beobachtungen in den Unterkretazische-Schichten des Mecsek-Gebirges) [Observations on the Lower Cretaceous beds of the Mecsek Mountains]. - Földtani Közlöny, 98/2, pp. 241-247. (in Hungarian)

Hoyoux, C., M. Zbinden, S. Samadi, F. Gaill, Ph. Compere 2009: Wood-based diet and gut microflora of a galatheid crab associated with Pacific deep-sea wood falls. - Marine Biology, 156, pp. 2421-2439.

Höglund, H. 1947: Foraminifera in the Gullmar Fjord and the Skagerak. - Zoologiska bidrag från Uppsala, $26,328 \mathrm{p}$.

Huemer, H. 1997: Multistage evolution of a volcanic suite in the Eastern Mecsek Mountains, Southern Hungary. - Mineralogy and Petrology, 59, pp. 101-120.

Jáger, V. 2008: Lower Cretaceous "black smoker" chimneys in pillow basalt beds in the Eastern Mecsek Mts. - Mineralogia, Special Papers, 32, p. 78.

Jáger, V., F. Molnár 2009: Lower Cretaceous continental rift-type black smoker system in the East Mecsek Mts. - Mitteilungen des Österreichischen Mineralogischen Gesellschaft, 155, p. 70.

Jáger, V., F. Molnár, D. Buchs, P. Koděra 2012: The connection between iron ore formations and "mudshrimp" colonizations around sunken wood debris and hydrothermal sediments in a Lower Cretaceous continental rift basin, Mecsek Mts. Hungary. - Earth-Science Reviews, 114, pp. 250-278.

Jochum, K.P., X. Wang, T.W. Vennemann, B. Sinha, W.E. Müller 2009: Siliceous sponge spicules as paleoenvironmental biomarkers of the deep-sea. - Eos, Transactions, American Geophysical Union Fall Meting Supplement, 90/52, pp. PP11C-1324.

Jonasson, K.E., C.J. Schröder-Adams, R.T. Patterson 1995: Benthic foraminiferal distribution at Middle Valley, Juan de Fuca Ridge, a northeast Pacific hydrothermal venting site. - Marine Micropaleontology, 25/2-3, pp. 151-167.

Jones, T.R., W.K. Parker 1860: On the rhizopodal fauna of the Mediterranean compared with that of the Italian and some other Tertiary deposits. - Quarterly Journal of the Geological Society of London, 16, pp. 292-307.

Karlen, D.J., R.E. Price, T. Pichler, J.R. Garey 2010: Changes in benthic macrofauna associated with a shallow-water hydrothermal vent gradient in Papua New Guinea. - Pacific Science, 64/3, pp. 391-404.

Kietzmann, D.A., J. Blau, D.E. Fernández, R.M. Palma 2010: Crustacean microcoprolites from the Upper Jurassic-Lower Cretaceous of the Neuquén Basin, Argentina: Systematics and biostratigraphic implications. - Acta Palaeontologica Polonica, 55/2, pp. 277-284.

Lethiers, F., S. Crasquin-Soleau 1988: Comment extraire les microfossiles à tests calcitiques des roches calcaires dures [How to extract calcitic microfossil tests from carbonatic hard rocks]. - Revue de Micropaléontologie, 31/1, pp. 56-61.

Mauritz, B. 1913: A Mecsek-hegység eruptivus kőzetei [Eruptive rocks of the Mecsek Mountains]. Annales of the Hungarian Royal Geological Institute, 21/6, pp. 151-190. (in Hungarian)

Mauritz, B. 1958: Két újabb vulkáni kőzettípus a Mecsek-hegységből (Zwei neue vulkanische Gesteinstypen aus dem Mecsekgebirge) [Two new types of volcanic rocks from the Mecsek Mountains]. - Földtani Közlöny, 88/1, pp. 42-47. (in Hungarian)

Molnár, J. 1961: A zengővárkonyi vasérckutatás [Iron ore exploration of Zengővárkony]. - Bányászati Lapok, 94/3, pp. 187-194. (in Hungarian)

Morri, C., C.N. Bianchi, S. Cocito, A. Peirano, A.M. De Biase, S. Aliani, M. Pansini, M. Boyer, F. Ferdeghini, M. Pestarino, P. Dando 1999: Biodiversity of marine sessile epifauna at an Aegean island subject to hydrothermal activity: Milos, eastern Mediterranean Sea. - Marine Biology, 135, pp. 729-739. 
Nagy, I. 1967: A felsőjura képződmények és a kréta vulkanitok viszonya a Mecsekben [Relations of the Upper Jurassic formations and the Cretaceous volcanites in the Mecsek Mountains]. - Annual Report of the Geological Institute of Hungary, 1965, pp. 149-168. (in Hungarian)

Palik, P. 1965: Remains of crustacean excrement from the Lower Cretaceous of Hungary. Micropalaeontology, 11, pp. 98-104.

Panieri, G., F. Gamberi, M. Marani, R. Barbieri 2005: Benthic foraminifera from a recent, shallow-water hydrothermal environment in the Aeolian Arc (Tyrrhenian Sea). - Marine Geology, 218/1-4, pp. 207-229.

Pantó, G., K. Varrók, G. Kopek 1955: A zengővárkonyi vasérckutatás földtani eredményei (Nouvelles contributions à la géologie du gisement de minerai de fer de Zengővárkony) [Geological results of the iron ore exploration at Zengővárkony]. - Földtani Közlöny, 85/2, pp. 125-144. (in Hungarian)

Parker, W.K., T.R. Jones 1865: On some foraminifera from the North Atlantic and Arctic Oceans, including Davis Straits and Baffin's Bay. - Philosophical Transactions of the Royal Society, 155, pp. 325-441.

Peckmann, J., B. Senowbari-Daryan, D. Birgel, J.L. Goedert 2007: The crustacean ichnofossil Palaxius associated with callianassid body fossils in an Eocene methane-seep limestone, Humptulips Formation, Olympic Peninsula, Washington. - Lethaia, 40/3, pp. 273-280.

Pohl, M.E. 1946: Ecological observations on Callianassa major Say at Beaufort, North Carolina. - Ecology, 27, pp. 71-80.

Sarano, F., R.C. Murphy, B.F. Houghton, J.W. Hedenquist 1989: Preliminary observations of submarine geothermal activity in the vicinity of White Island Volcano, Taupo Volcanic Zone, New Zealand. Journal of the Royal Society of New Zealand, 19/4, pp. 449-459.

Savin, L. 1905: Révision des Échinides fossiles du département de l'Isére [Revision of the fossil Echinids of the Isére region]. - Impr. Descotes, Grenoble, $220 \mathrm{p}$.

Schweigert, G., D. Seegis, A. Fels, R.R. Leinfelder 1997: New internally structured microcoprolites from Germany (Late Triassic/Early Miocene) Southern Spain (Early/Middle Jurassic) and Portugal (Late Jurassic): Taxonomy, palaeoecology and evolutionary implications. - Paläontologische Zeitschrift, 71/1-2, pp. 51-69.

Senowbari-Daryan, B., G.D. Stanley 1986: Thalassinid anomuran microcoprolites from Upper Triassic carbonate rocks of central Peru. - Lethaia, 19, pp. 343-354.

Senowbari-Daryan, B., P. Schaefer, R. Catalano 1969: Helicerina siciliana n. sp., a new anomuran coprolite from Upper Triassic reef limestone near Palermo (Sicily). - Bollettino della Società Paleontologica Italiana, 18/2, pp. 315-319.

Senowbari-Daryan, B., V.V. Silantiev 1991: New crustacean coprolites from the Upper Paleocene of North Caucasus. - Mitteilungen der Gesellschaft der Geologie- und Bergbaustudenten in Österreich, 37, pp. $75-82$.

Sievert, S.M., T. Brinkhoff, G. Muyzer, W. Ziebis, J. Kuever 1999: Spatial heterogeneity of bacterial populations along an environmental gradient at a shallow submarine hydrothermal vent near Milos Island (Greece). - Applied and Environmental Microbiology, 65/9, pp. 3834-3842.

Stewart, I.R. 1981: Population structure of articulate brachiopod species from soft and hard substrates. New Zealand Journal of Zoology, 8/2, pp. 197-207.

Szinger, B. 2008: Early Cretaceous foraminifera from atoll environment (Márévár Valley, Mecsek Mountains, Hungary). - Hantkeniana, 6, pp. 127-143.

Szörényi, E. 1961: Magyarországi mezozóos echinodermaták [Mesozoic Echinoidea of Hungary]. - Annales of the Geological Institute of Hungary, 49/1, pp. 255-259. (in Hungarian)

Szörényi, E. 1965: Échinides du Crétacé inférieur de la Hongrie. - Geologica Hungarica series Palaeontologica, 29-32, pp. 293-367.

Sztrókay, K.I. 1952: Mecseki vasércképződés [Iron ore genesis in the Mecsek Mountains]. - Magyar Tudományos Akadémia Müszaki Osztályának Közleményei, 3, pp. 11-23. (in Hungarian)

Tokeshi, M. 2011: Spatial structures of hydrothermal vents and vent-associated megafauna in the back-arc basin system of the Okinawa Trough, western Pacific. - Journal of Oceanography, 67, pp. 651-665. 
Vacelet, J. 2006: New carnivorous sponges (Porifera, Poecilosclerida) collected from manned submersibles in the deep Pacific. - Zoological Journal of the Linnean Society, 148/4, pp. 553-584.

Vadász, E. 1935: A Mecsekhegység (Das Mecsek-Gebirge) [The Mecsek Mountains]. - Hungarian Royal Geological Institute, Budapest, 208 p. (in Hungarian)

Van Dover, C.L., D. Desbruyères, M. Segonzac, T. Comtet, L. Saldanha, A. Fiala-Médioni, Ch. Langmuir 1996: Biology of the Lucky Strike hydrothermal field. - Deep-Sea Research I, 43/9, pp. 1509-1529.

Walker, G., E. Jacob 1798: Descriptions of Serpula (Lagena) sulcata and Nautilus lobatulus. - In: Adams, E. (Ed): Essays on the Microscope (2nd ed.). Dillon and Keating, London, pp. 634-642.

Wein, Gy. 1961: A szerkezetalakulás mozzanatai és jellegei a Keleti-Mecsekben [Moments and characters of the structural development in the Eastern Mecsek Mountains]. - Annales of the Geological Institute of Hungary, 49/3, pp. 759-768. (in Hungarian)

Wein, Gy. 1965: A Mecsek-hegység "Északi Pikkely"-ének földtani felépítése [Geological setting of the "Northern Imbrication" in the Mecsek Mountains]. - Annual Report of the Geological Institute of Hungary, 1963, pp. 35-52.

Williamson, W.C. 1858: On the Recent Foraminifera of Great Britain. - Ray Society, London, $100 \mathrm{p}$.

Wolff, T. 2005: Composition and endemism of the deep-sea hydrothermal vent fauna. - Cahiers de Biologie Marine, 46, pp. 97-104.

Zhirmunsky, A.V., V.G. Tarasov 1990: Unusual marine ecosystem in the flooded crater of Ushisher volcano. - Marine Ecology Progress Series, 65, pp. 95-102. 